\title{
Perancangan Aplikasi Penjaminan Mutu di Fakultas Ilmu Komputer Universitas Katolik Santo Thomas
}

\author{
Josua Van Mitchelle Situmorang ${ }^{1}$, Lamhot Sitorus ${ }^{2}$ \\ ${ }^{12}$ Universitas Katolik Santo Thomas Medan, Jl. Setiabudi No. 479 F Tanjungsari, Medan, Indonesia
}

\begin{tabular}{|c|}
\hline ARTICLE INFORMATION \\
\hline $\begin{array}{l}\text { Received: Agustus 28, } 2021 \\
\text { Revised: September 12, } 2021 \\
\text { Available online: Oktober, } 2021\end{array}$ \\
\hline KEYWORDS \\
\hline $\begin{array}{l}\text { Jaminan Mutu, Universitas, Fakultas, Kualitas } \\
\text { Perguruan Tinggi }\end{array}$ \\
\hline CORRESPONDENCE \\
\hline $\begin{array}{l}\text { Phone: +6285277742435 } \\
\text { E-mail:lamhot68@yahoo.com, } \\
\text { vinnyyanapurba@gmail.com }\end{array}$ \\
\hline
\end{tabular}

\section{A B S T R A K}

Mutu pendidikan pada dasarnya terdiri atas berbagai indikator dan komponen yang saling berkaitan, Penelitian ini dilakukan untuk memperoleh penjaminan Mutu Fakultas pada Fakultas Ilmu Komputer Universitas Katolik Santo Thomas. Ruang lingkup yang meliputi visi misi, kurikulum, jurnal dan penelitian pada dosen. Visi Misi Fakultas dan Visi Misi Program Studi bertujuan untuk memiliki arah dan tujuan kedepannya agar menjadi lebih baik dan tercapai untuk masa depan Fakultas Ilmu Komputer. Ruang lingkup monitoring dan evaluasi yang sudah dilaksanakan yang meliputi kurikulum, visi misi, jurnal dan penelitian

\section{PENDAHULUAN}

Konsep mutu telah menjadi suatu kenyataan dan fenomena dalam seluruh aspek dan dinamika masyarakat global memasuki persaingan pasar bebas dewasa ini. Jika sebelumnya kualitas produk dan jasa hanya menjadi target dari dunia bisnis dan industri yang bergantung pada kepuasan pelanggan atau konsumen, maka kini dunia pendidikan mulai menerapkan hal yang sama dalam menghasilkan mutu lulusan yang mampu menjawab kebutuhan pasar kerja.

Mutu pendidikan pada dasarnya terdiri atas berbagai indikator dan komponen yang saling berkaitan. Komponen dan variabel yang menentukan terwujudnya mutu pendidikan yang baik secara umum masih dikaitkan dengan sistem, kurikulum, tenaga pendidik, peserta didik, proses belajar mengajar, anggaran, sarana prasarana pendidikan, lingkungan belajar, budaya organisasi, dan kepemimpinan. Mutu kepemimpinan tidak diukur hanya berdasarkan hasil ujian atau test peserta didik, karena memiliki rangkaian yang saling berhubungan mulai dari input, proses, output dan outcome.

Menurut Sumantrie mutu pendidikan adalah konsep yang kompleks karena mutu pendidikan memiliki banyak dimensi, menyangkut serangkaian proses, dan menunjukan berbagai indikator yang harus dijelaskan secara rinci.

Dalam kaitannya dengan mutu pendidikan, pemerintah telah mengeluarkan UU Nomor 20 tahun 2003 tentang Sisdiknas pasal 1 ayat (21) yaitu evaluasi pendidikan adalah kegiatan pengendalian, penjaminan, dan penetapan mutu pendidikan terhadap berbagai komponen pendidikan pada jalur, jenjang pendidikan sebagai bentuk pertanggungjawaban penyelenggaraan pendidikan.

Pemerintah juga mengeluarkan PP No.19 tahun 2005 tentang Standar Nasional Pendidikan, pasal 91 ayat (1) yang menyatakan bahwa setiap satuan pendidikan pada jalur formal dan non formal wajib melakukan penjaminan mutu pendidikan, hal ini sebagai bentuk pertanggungjawaban para penyelenggara pendidikan.

Perguruan tinggi merupakan salah satu lembaga penyedia jasa layanan masyarakat di bidang pendidikan dituntut menjamin mutu pendidikan tinggi yang diselenggarakan. Untuk itu perguruan tinggi sebagai penyelenggara pendidikan harus melaksanakan suatu manajemen mutu terpadu, termasuk di dalamnya Sistem Jaminan Mutu Pendidikan agar mutu pendidikan perguruan tinggi dapat dipertahankan dan ditingkatkan sesuai dengan yang direncanakan atau yang dijanjikan. Keberadaan lembaga penjaminan mutu perguruan tinggi adalah sebuah keharusan sebagai upaya setiap perguruan tinggi memberikan jaminan mutu proses dan hasil pendidikan kepada stakeholders baik internal maupun eksternal perguruan tinggi.

Penerapan Penjaminan Mutu Perguruan Tinggi dinilai baik yaitu dengan melihat kesesuaian perencanaan dan pelaksanaan, adanya dokumen akademik, dokumen mutu, manual mutu, standar mutu, kebijakan mutu, SOP mutu, dan formulir mutu, baik dilakukan di tingkat Universitas, Fakultas hingga program studi. Dalam buku Pedoman Penjaminan Mutu Pendidikan Tinggi oleh Ditjen dikti menjelaskan tentang pelaksanaan penjaminan mutu di Perguruan Tinggi.

Peningkatan kemampuan untuk mengelola dan mengembangkan perguruan tinggi sudah sangat dirasakan perlu, termasuk untuk menggunakan prinsip-prinsip manajemen modern yang berorientasi pada mutu/kualitas. Hakekat dari sistem manajemen mutu perguruan tinggi berinti pada perbaikan terus menerus untuk memperkuat dan mengembangkan mutu lulusan sehingga dapat diserap oleh kalangan instansi dan pasar tenaga kerja. Sebagaimana diketahui bahwa era globalisasi adalah era persaingan mutu atau kualitas dari suatu produk. Kenyataan menunjukkan bahwa mutu lulusan Perguruan Tinggi tidak selalu dapat diterima dan mampu untuk bekerja sebagaimana yang diharapkan dunia kerja. Banyaknya Perguruan Tinggi dan program studi yang dibuka akan menurunkan mutu lulusan, karena standarisasi mutu lulusan tidak menjadi tujuan tetapi hanya dilihat dari aspek kuantitas yakni bagaimana mendapatkan jumlah mahasiswa yang banyak.

Pelayanan yang baik kepada mahasiswa menjadi cerminan keseriusan dosen selaku tenaga pendidik dalam melaksanakan tugas professional yang di berikan oleh Universitas katolik Santo Thomas. Keseriusan mahasiswa dalam mengikuti perkuliahan dapat di ukur dari kehadiran dan prestasi yang di peroleh mahasiswa setiap tahunnya. Hasil pemantauan 
yang dilakukan terhadap kinerja dosen serta hasil yang di peroleh oleh mahasiswa diharapkan dapat menjadi masukan dan pertimbangan dalam melakukan tindakan pada tiap semester.

Hasil monitoring dan evaluasi yang sudah dilakukan hasil yang diperoleh diharapkan dapat menjadi masukan bagi Dekan dan Ketua Program Studi sebagai bahan pertimbangan dalam membenahi Fakultas untuk meningkatkan mutu Pendidikan di Fakultas Ilmu Komputer. Ruang lingkup monitoring dan evaluasi yang sudah dilaksanakan yang meliputi kurikulum, visi misi, jurnal dan penelitian.

Mutu adalah ukuran relatif dari kebendaan. Mendefinisikan mutu dalam rangka kebendaan sangat umum sehingga tidak menawarkan makna oprasional. Secara oprasional mutu produk atau jasa adalah sesuatu yang memenuhi atau melebihi ekspektasi pelanggan. Sebenarnya mutu adalah kepuasan pelanggan. Ekspektasi pelanggan bisa dijelaskan melalui atribut-atribut mutu atau hal-hal yang sering disebut sebagai dimensi mutu. Oleh karena itu, mutu produk atau jasa adalah sesuatu yang memenuhi atau melebihi ekspektasi pelanggan dalam delapan dimensi mutu. Empat dimensi pertama menggambarkan atributatribut mutu penting, tetapi sulit mengukurnya. Delapan dimensi mutu adalah:

1. Kinerja (Performance), merupakan tingkat konsistensi dan kebaikan fungsi-fungsi produk

2. Estetika (Aesthetic), berhubungan dengan penampilan wujud produk

3. Kemudahan perawatan dan perbaikan (service ability), berhubungan dengan tingkat kemudahan merawat dan memperbaiki produk

4. Keunikan (features), menunjukan karakteristik produk yang berbeda secara fungsional dari produk sejenis.

5. Reliabilitas (Reliability), berhubungan dengan probabilitas produk dan jasa menjalankan fungsi dimaksud dalam jangka waktu tertentu.

6. Durabilitas (Durability), menunjukan umur manfaat dari fungsi produk

7. Tingkat kesesuaian ( Quality of conformance), menunjukan ukuran mengenai apakah sebuah produk atau jasa telah memenuhi spesifikasinya.

8. Pemanfaatan (fitness of use), menunjukan kecocokan dari sebuah produk menjalankan fungsi-fungsi sebagaimana yang diiklankan.

Tidak ada definisi mutu yang dibuat secara universal namun dari definisi-definisi yang diungkapkan para pakar mutu terdapat kesamaaan. Mutu adalah ukuran yang dibuat oleh konsumen atas produk dilihat dari segala dimensi, untuk memenuhi tuntutan kebutuhan, keamanan, kenyamanan serta kemudahan konsumen.

Supriono hanya mengakui dua dari tiga jenis mutu yang diungkapkan oleh Leviene Ramsey dan Berenson, dua jenis mutu yang diakui oleh Supriono (2002: 377), yakni :

1. Mutu Rancangan (Quality of design)

Mutu Rancangan adalah suatu fungsi berbagai spesifikasi produk. Mutu rancangan merupakan nilai yang dirumuskan menurut tingkatannya. Mutu yang lebih tinggi tidak selalu merupakan mutu yang lebih baik. Suatu produk yang terlampau canggih karena tidak mengindahkan kebutuhan konsumen akan memiliki kelebihan mutu, dan akan menjadi terlampau mahal untuk bersaing. Teknologi pengendalian dan pembuatan yang tersedia harus dipertimbangkan dengan seksama dalam menetapkan sasaran mutu rancangan. mutu rancangan yang lebih tinggi biasanya ditunjukkan oleh dua hal yaitu : tingginya biaya pemanufakturan dan tingginya harga jual.

2. Mutu Kesesuaian (Quality of conformance)

Mutu kesesuaian adalah suatu ukuran mengenai bagaimana suatu produk memenuhi berbagai persyaratan atau spesifikasi. Jika suatu produk memenuhi semua spesifikasi rancangan, produk tersebut cocok digunakan. Sebuah produk yang dibuat tepat sebagaimana didseain sejak awal adalah produk yang baik, dan produk yang tidak memenuhi standar desainnya adalah cacat.

Universitas adalah tempat dimana mencari pendidikan setelah lulus SMA. Di universitas inilah kehidupan untuk menjadi seorang yang dewasa akan dimulai. Di tempat inilah sebutan anda yang awalnya adalah seorang siswa akan berubah menjadi mahasiswa yang artinya lingkupnya lebih besar. Di sinilah wadah untuk menyalurkan aspirasi mengeluarkan semua kemampuan yang kita punya mempraktikkan skill yang dipunya dan lain sebagainya. Seperti Unit Kegiatan Mahasiswa disitulah tempat menampung kemampuan, seperti musik, teater, Paduan suara, kewirausaahaan, dan lain sebagainya. Bahkan ketika tidak memiliki skill di bidang itu tapi benar benar memiliki niat untuk mengikuti UKM itu pasti ada jalan untuk bisa, karena disinilah tempat kita belajar dan bertemu dengan orang yang lebih pintar. Dan yang paling penting di Universitas ini tempat untuk mulai belajar berorganisasi.

Fakultas adalah bawahan dari Universitas. Ibarat sebuah negara Universitas sebagai negaranya dan fakultas sebagai provinsinya. Jadi disetiap Universitas terdiri atas beberapa Fakultas, misalnya Fakultas Ilmu Pendidikan, Fakultas Kesehatan, Fakultas Ekonomi, Fakultas Kedokteran, Fakultas Hukum, Fakultas Teknik, Fakultas Agama Islam dan lain sebagainya. Tujuan dibentuknya fakultas ini agar mahasiswa memiliki kekhususan kemana mereka akan belajar dan menekuni skill yang dipunya. Seperti halnya universitas, fakultas juga memiliki organisasi organisasi yang berada dalam lingkup fakultas misalnya seperti HIMA, HMJ dan lain sebagainya.

\section{METODE PENELITIAN}

Untuk mencapai tujuan yang telah dirumuskan sebelumnya, maka metodologi yang digunakan dalam penulisan ini adalah:

1. Perumusan ide-ide topik penelitian dan mengidentifikasikan permasalahan

Pada tahap pertama, dilakukan pencarian tema-tema yang menarik untuk diangkat, baik dari pencarian pada situs-situs internet, jurnal, maupun buku.

2. Studi literatur dasar teori penelitian

Dilakukan studi literatur untuk menentukan landasan teori yang berhubungan dengan topik penelitian ini sebagai dasar dalam pelaksanaan penelitian. Landasan teori ini kemudian akan dijadikan acuan dalam pelaksanaan tugas akhir. Adapun landasan teori yang terkait dengan penelitian ini diantaranya adalah Teori visi misi,angket kurikulum, angket visi misi, angket, jurnal dosen, penelitian dosen dan pengabdian dosen.

3. Perumusan masalah

Perancangan Aplikasi Penjaminan Mutu di Fakultas Ilmu Komputer Universitas Katolik Santo Thomas

Oleh : Josua Van Mitchelle Situmorang, Lamhot Sitorus 
Berdasarkan identifikasi masalah dan studi literatur teori, dapat dirumuskan masalah dalam penelitian ini, yaitu perlu dilakukannya monitoring dan evaluasi jaminan mutu Fakultas Ilmu Komputer Universitas Katolik Santo Thomas.

4. Penentuan topik penelitian

Adapun topik dari penelitian ini adalah Perancangan Aplikasi Penjaminan Mutu Pada Fakultas Ilmu Komputer

Universitas Katolik Santo Thomas.

5. Penentuan tujuan penelitian

Adapun tujuan penelitian ini adalah memperoleh penjaminan mutu fakultas tentang seberapa paham dosen, tata usaha dan mahasiswa mengenai visi misi fakultas, seberapa paham dosen dan mahasiswa mengenai kurikulum,penelitian dosen, jurnal dosen dan penelitian dosen.

6. Pengumpulan data

Dalam melakukan penelitian ini, data yang dibutuhkan adalah data setiap data dosen,tata usaha dan mahasiswa yang ada di fakultas ilmu komputer dan sejumlah pertanyaan mengenai visi misi dan kurikulum. Pada tahapan ini, dilakukan pengolahan data dari data yang sudah diperoleh.

7. Merancang pembuatan aplikasi Model Penjaminan Mutu

Mengimplementasikan rancangan sistem dengan cara membangun serta membuat Perancangan Aplikasi Penjaminan Mutu Pada Fakultas Ilmu Komputer Universitas Katolik Santo Thomas.

8. Menguji perangkat lunak yang sudah dibuat kemudian menganalisa hasil output apakah sudah sesuai tujuan yang sudah dirumuskan \& optimal.

Pada tahap ini menulis laporan penelitian sebagai dokumentasi dari penelitian yang meliputi penulisan teori penunjang, perancangan-perancangan perangkat lunak, pembuatan perangkat lunak, uji coba perangkat lunak, serta analisis dan kesimpulan.

\section{HASIL DAN PEMBAHASAN}

Berdasarkan gambar 1 menjelaskan bahwa pada sistem yang dibangun tersebut terdapat 2 aktor yaitu: admin, kaprodi/operator. Berikut ini penjelasan dari tugas masing-masing aktor.

1. Admin

Admin pertama melakukan login terlebih dahulu, agar admin masuk ke dashboard admin dan dapat mengelola data user(dosen,tata usaha,mahasiswa), data angket(kurikulum dan visi misi),jurnal dan penelitian

2. Dosen

Dosen terlebih dahulu melakukan login setelah itu dosen masuk ke halaman dashboard untuk mengisi quisioner mengenai visi misi fakultas, angket kurikulum serta menambah jurnal atau penelitian.

3. Tata Usaha

Tata Usaha terlebih dahulu melakukan login setelah itu Tata Usaha masuk ke halaman dashboard untuk mengisi quisioner mengenai visi misi fakultas.

4. Mahasiswa

Mahasiswa terlebih dahulu melakukan login setelah itu Mahasiswa masuk ke halaman dashboard untuk mengisi quisioner mengenai visi misi fakultas, angket, seperti gambar 1:

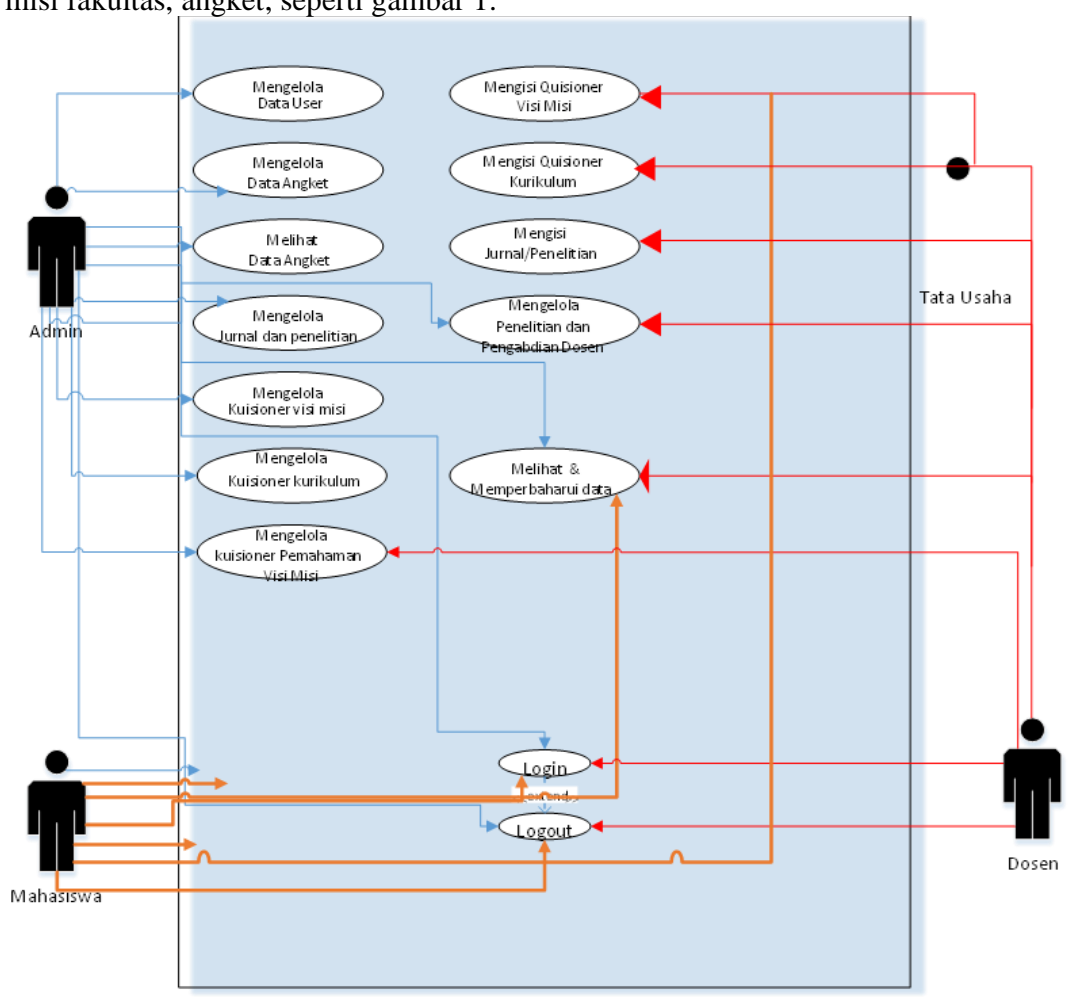

Gambar 1. Use Case Diagram

Perancangan Aplikasi Penjaminan Mutu di Fakultas Ilmu Komputer Universitas Katolik Santo Thomas 
Gambar 2. berikut adalah tampilan antar muka menu login. Form login akan muncul ketika program pertama kali di jalankan.

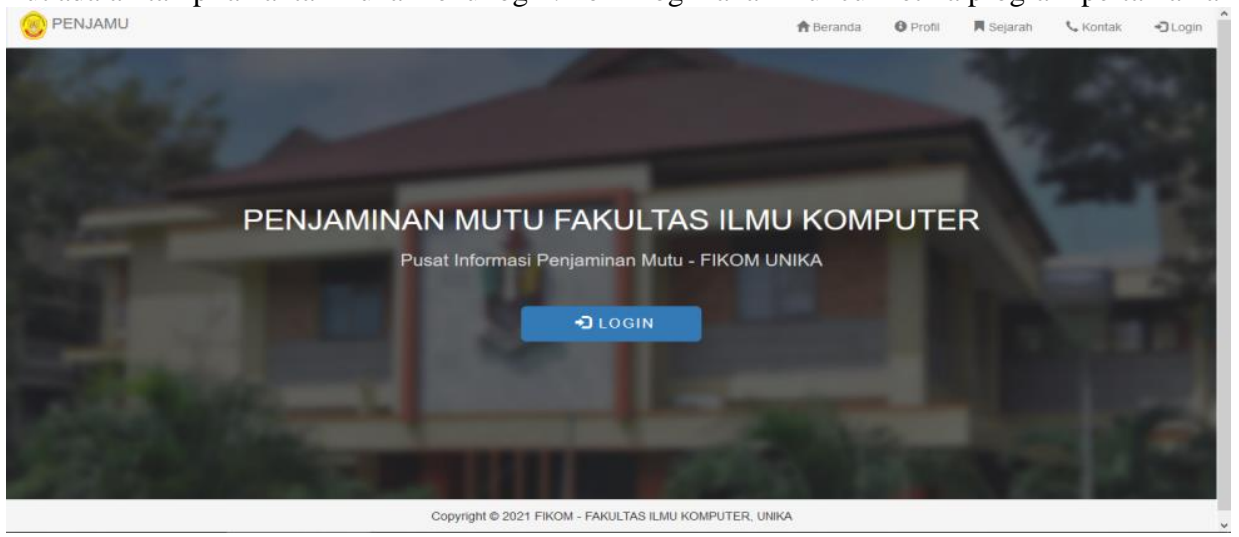

Gambar 2. Form Login

Gambar 3. berikut adalah tampilan antar muka menu dashboard. Menu ini dapat di akses admin setelah login terlebih dahulu.

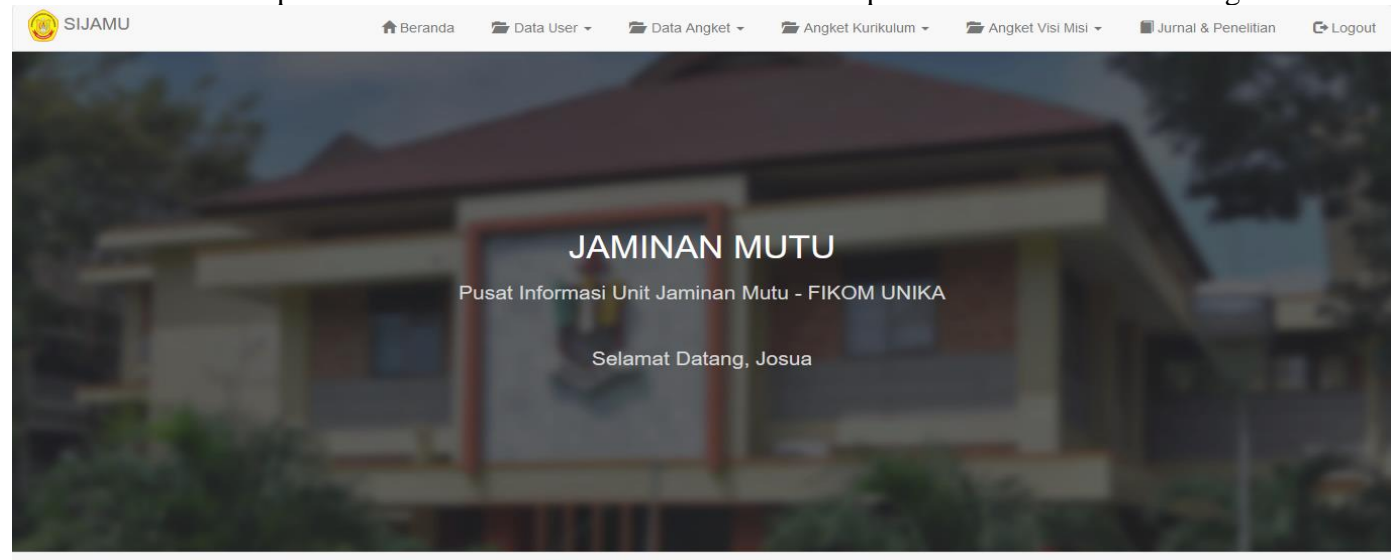

Copyright $\odot 2021$ Fakultas IIImu Komputer, UNIKA

Gambar 3. Halaman Dashboard

Gambar 4. berikut adalah tampilan antar muka menu profil. Disini admin memanipulasi data profil dosen, tata usaha dan mahasiswa untuk edit data.

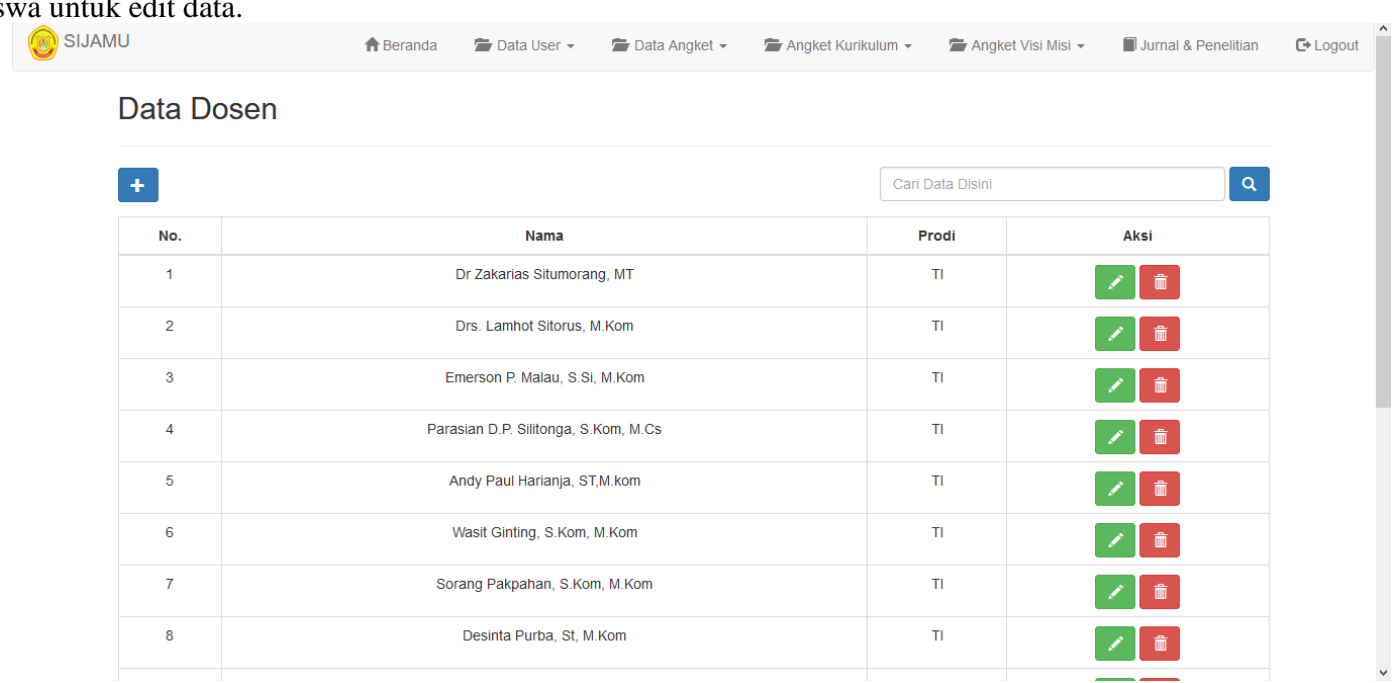

Gambar 4. Halaman Data Profil

Gambar 5.berikut adalah proses untuk menambah Data, langkah yang harus dilakukan adalah mengklik tombol Tambah lalu mengisi Field Maka Pengisian tambah data dosen, tata usaha, mahasiswa adalah sebagai berikut: 


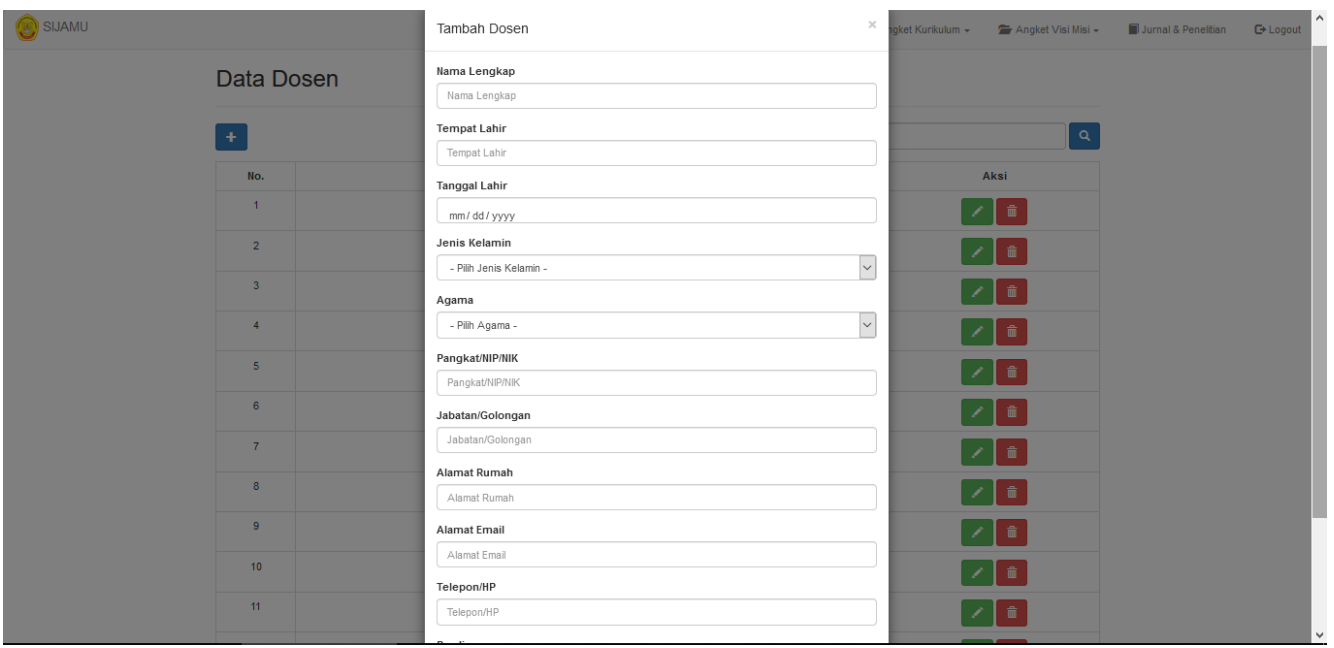

Gambar 5. Halaman Tambah Data Profil

Gambar 6. berikut adalah proses untuk ubah data, langkah yang harus dilakukan adalah meng-klik icon edit lalu dapat mengubah Field data yang ada.
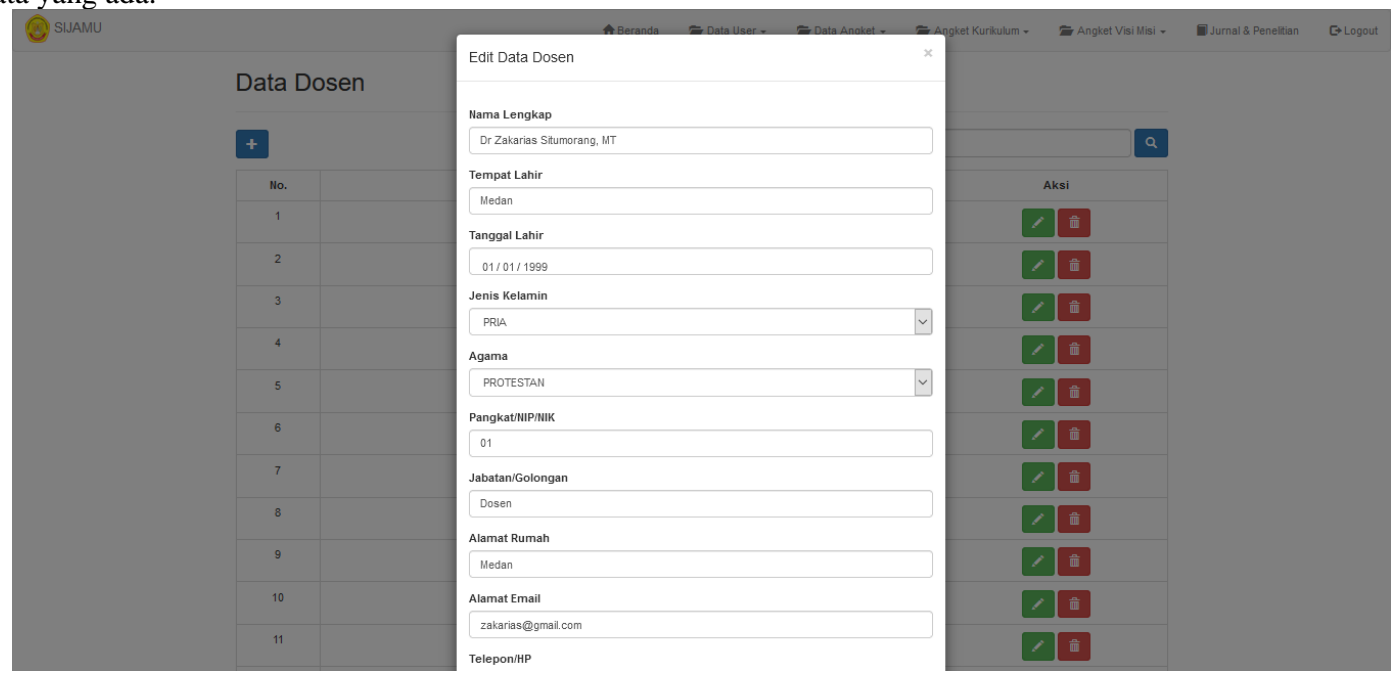

Gambar 6. Halaman Edit Data

Gambar 7. berikut adalah proses untuk ubah data, langkah yang harus dilakukan adalah meng-klik icon edit lalu dapat menghapus Field data yang ada.

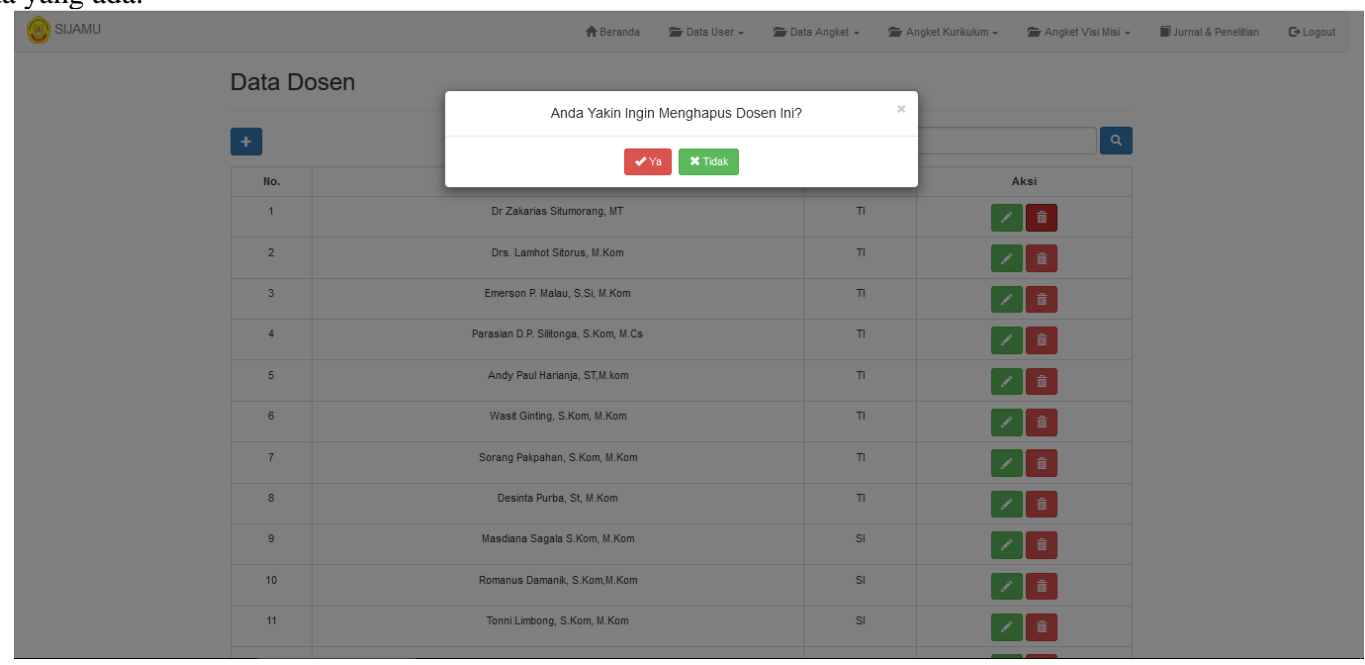

Gambar 7. Halaman Hapus Data

Gambar 8. berikut adalah tampilan antar muka menu data kurikulum. Disini admin memanipulasi data angket kurikulum untuk menambah, edit dan menghapus. 


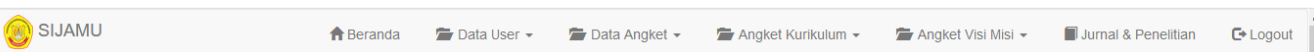

Data Angket Kurikulum

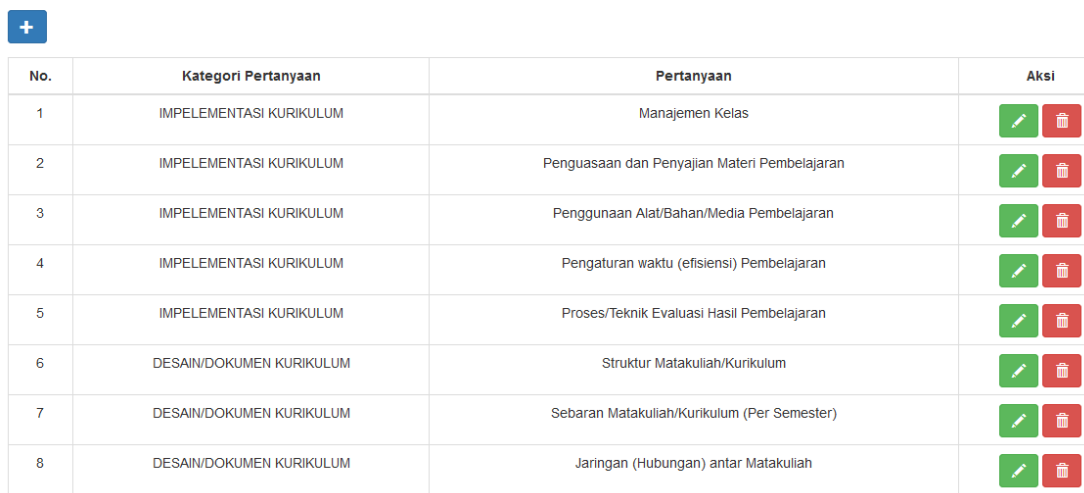

Gambar 8. Halaman Angket Kurikulum

Gambar 9. berikut adalah proses untuk menambah Angket kurikulum, langkah yang harus dilakukan adalah mengklik tombol Tambah lalu mengisi Field Maka Pengisian tambah angket kurikulum akan ditambahkan adalah sebagai berikut:

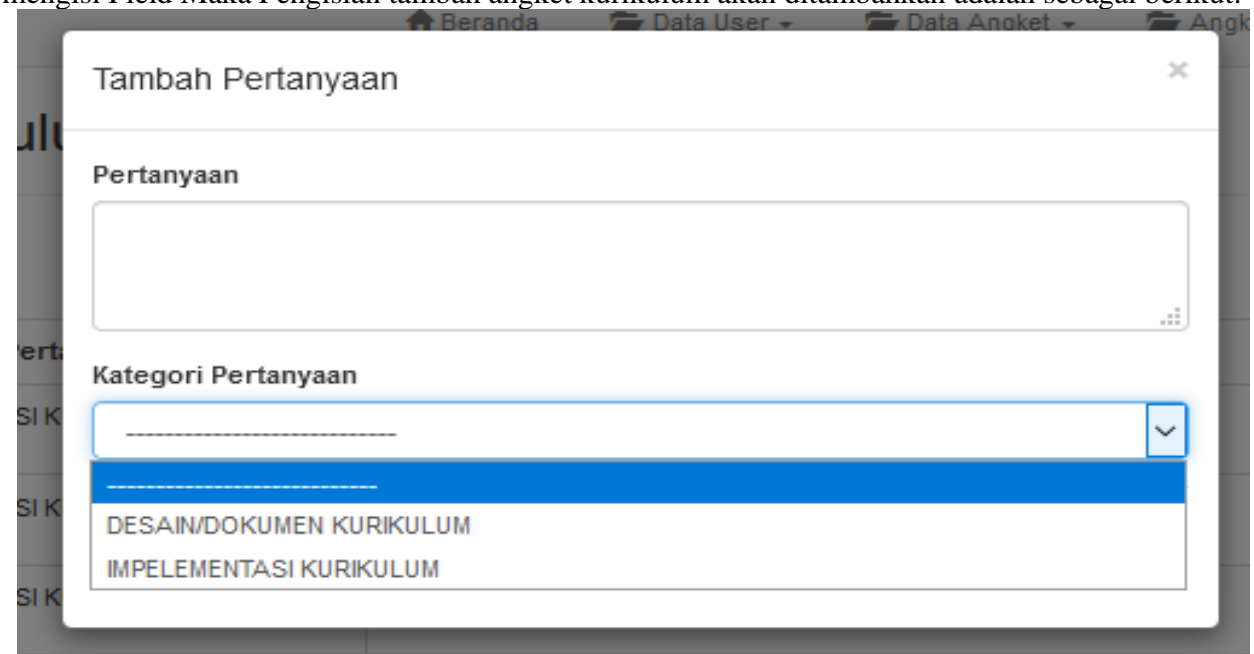

Gambar 9. Halaman Tambah Angket Kurikulum

Gambar 10. berikut adalah proses untuk ubah data, langkah yang harus dilakukan adalah meng-klik icon edit lalu dapat mengubah Field data yang ada.

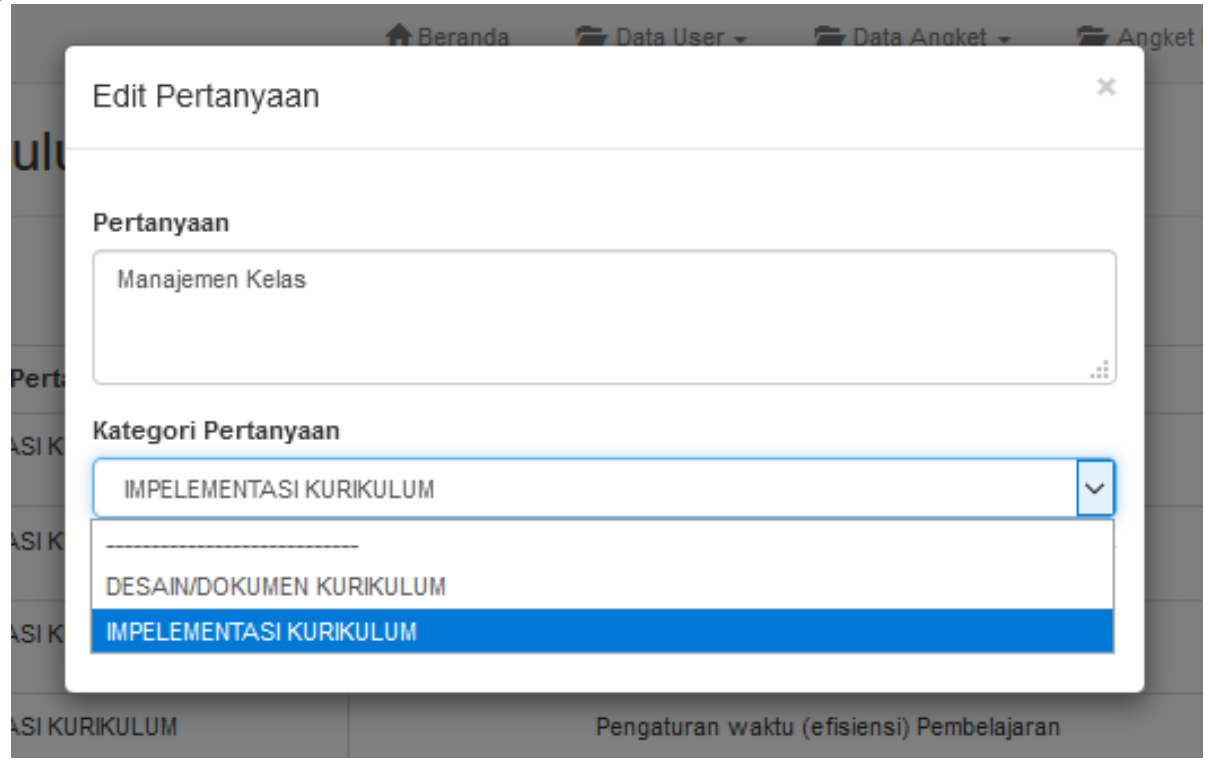

Gambar 10. Halaman Edit Angket Kurikulum 
Gambar 11. berikut adalah proses untuk ubah data, langkah yang harus dilakukan adalah meng-klik icon edit lalu dapat menghapus Field data yang ada.

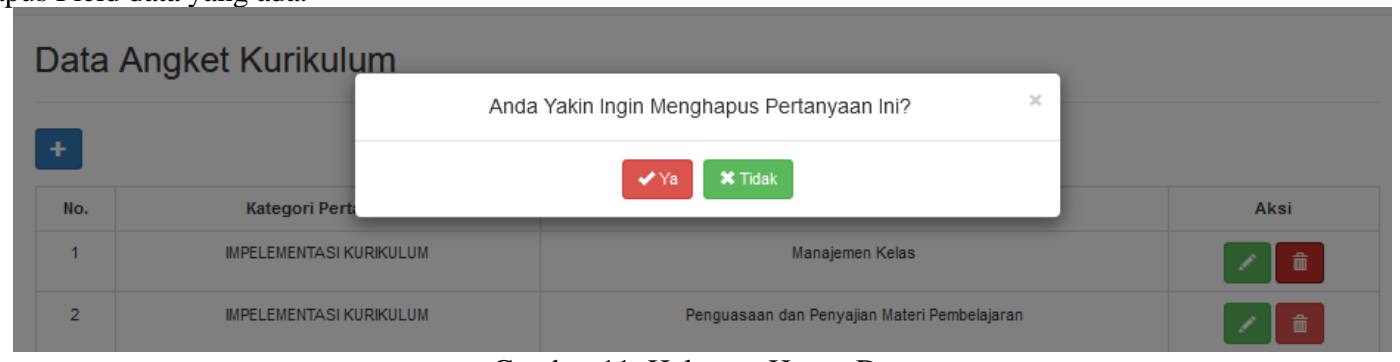

Gambar 11. Halaman Hapus Data

Gambar 12. berikut adalah tampilan antar muka menu angket visi misi. Disini admin memanipulasi data angket visi misi dosen, tata usaha dan mahasiswa untuk menambah, edit dan menghapus.

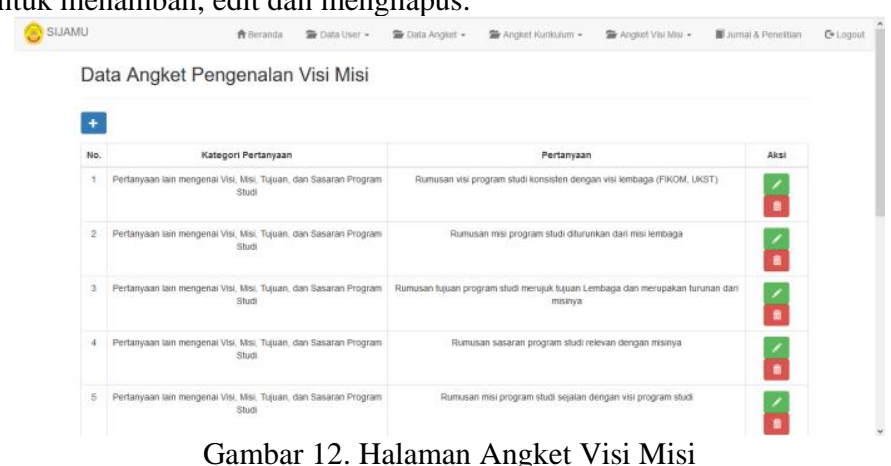

Gambar 12. Halaman Angket Visi Misi

Gambar 13. berikut adalah proses untuk menambah Data Visi Misi, langkah yang harus dilakukan adalah mengklik tombol Tambah lalu mengisi Field Maka Pengisian tambah data visi misi adalah sebagai berikut:

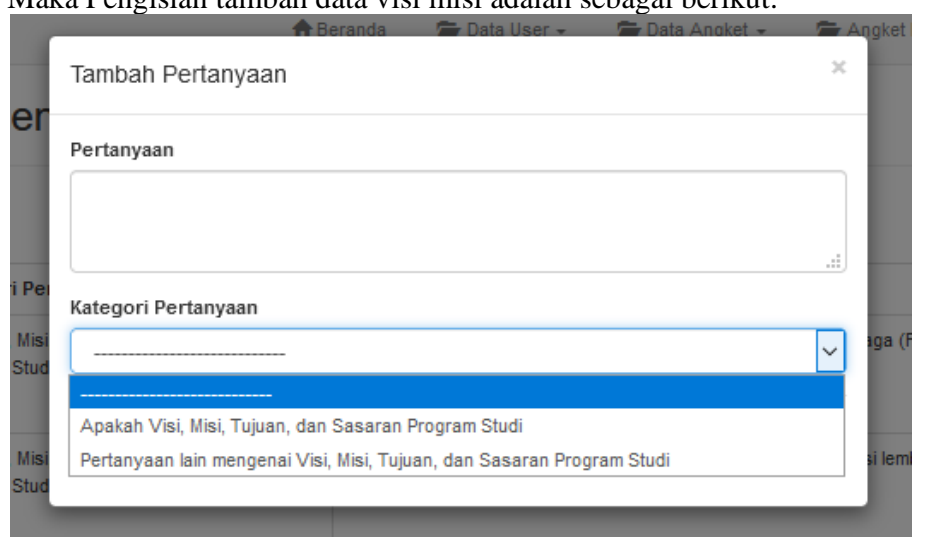

Gambar 13. Halaman Tambah Angket Visi Misi

Gambar 14. berikut adalah proses untuk ubah data, langkah yang harus dilakukan adalah meng-klik icon edit lalu dapat mengubah Field data yang ada.

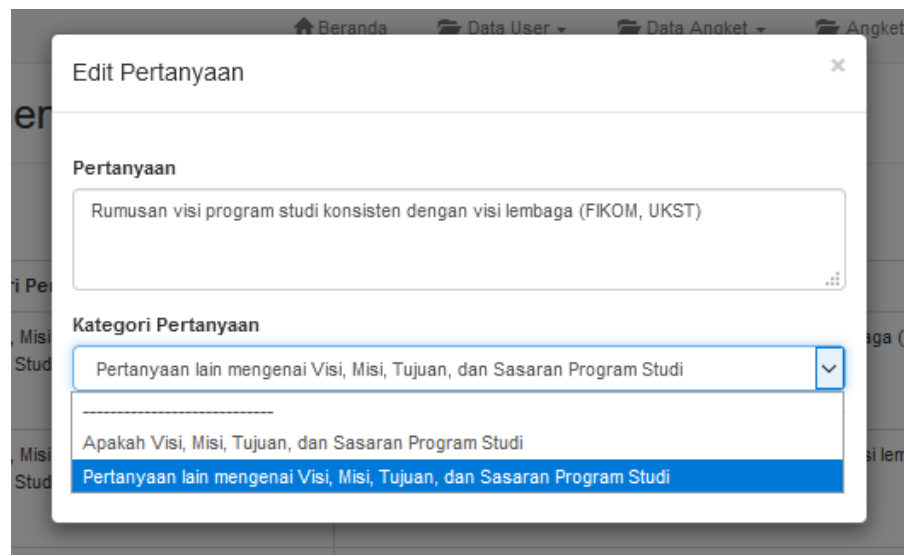

Gambar 14. Halaman Edit Angket Visi Misi 
Gambar 15. berikut adalah contoh penilaian untuk visi misi dan kurikulum yang terdiri dari grafik penentuan berdasarkan nilai yang ada dan terdapat nama nama yang sudah mengisi data tersebut.

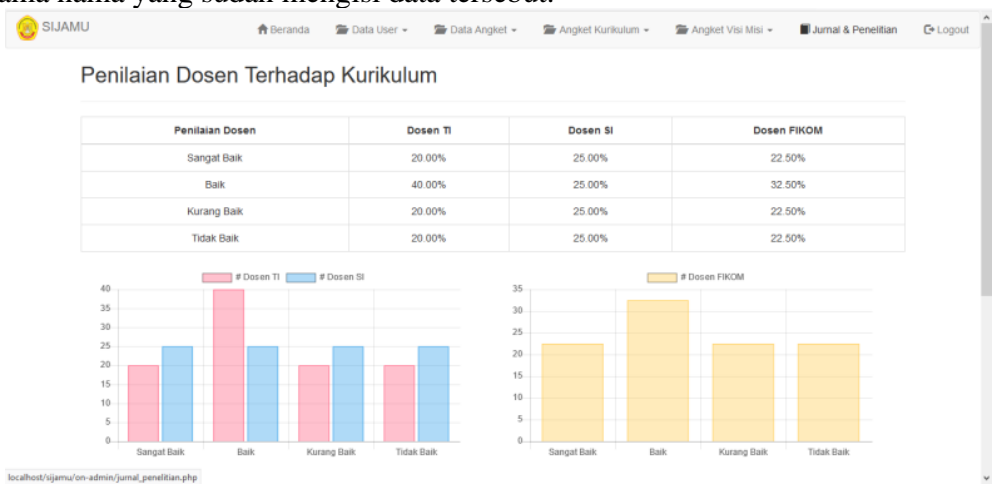

Gambar 15 Form Data Penilaian

Gambar 16 berikut adalah contoh penilaian untuk jurnal dan penelitian dosen yang terdiri dari grafik penentuan berdasarkan data yang ada dan terdapat nama nama yang sudah mengisi data tersebut.

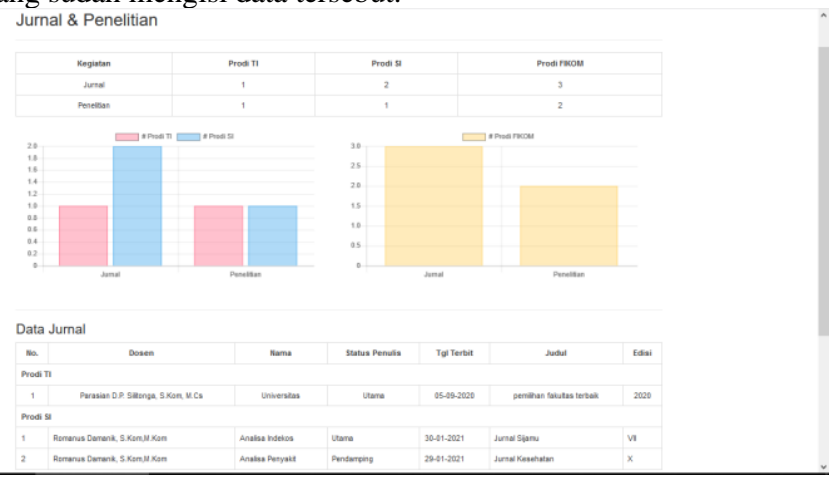

Gambar 16. Form Data Penilaian Jurnal dan Penelitian

Gambar 17. berikut adalah proses untuk menambah Data Penelitian langkah yang harus dilakukan adalah mengklik tombol Tambah lalu mengisi Field Maka Pengisian tambah data visi misi adalah sebagai berikut:

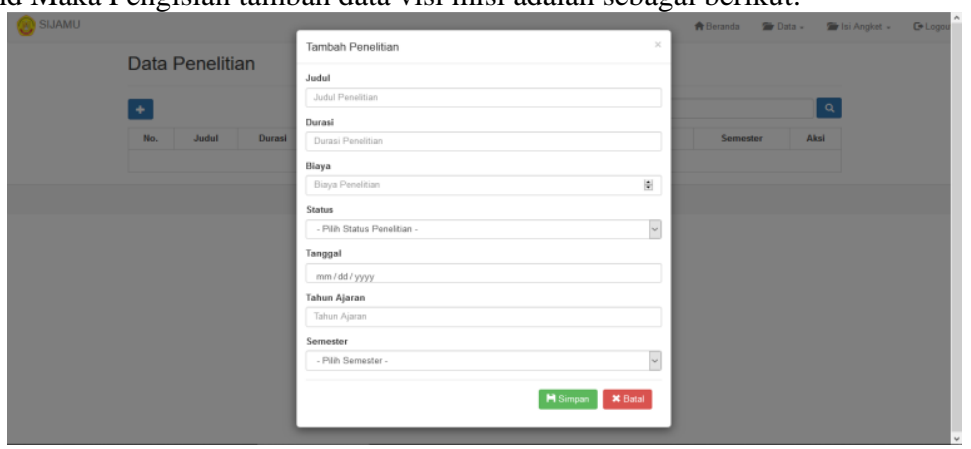

Gambar 17. Tambah Data Penelitian

Gambar 18. berikut adalah proses untuk menambah Data Jurnal, langkah yang harus dilakukan adalah mengklik tombol Tambah lalu mengisi Field Maka Pengisian tambah data visi misi adalah sebagai berikut:

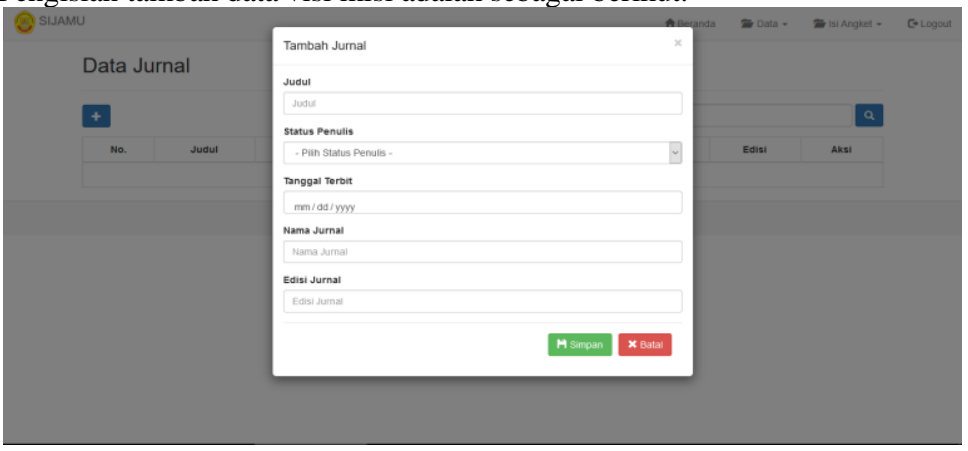

Gambar 18. Tambah Data Jurnal 
Gambar 19. berikut adalah contoh isi angket Kurikulum untuk dosen dan mahasiswa yang ada didalam data yang terdiri dari pilihan jawaban sangat baik,baik,kurang baik dan sangat baik.

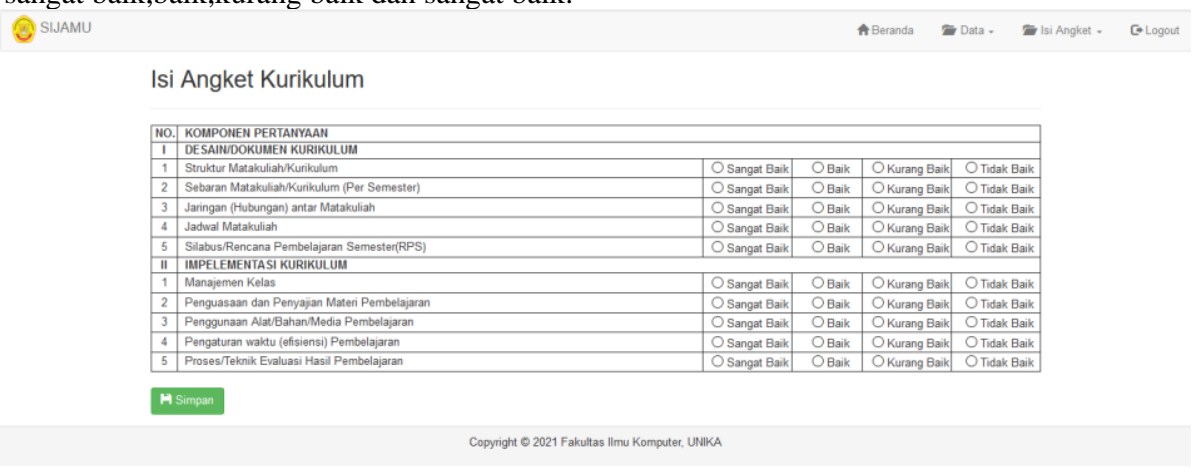

Gambar 19. Pengisian Angket Kurikulum

Gambar 20 berikut adalah contoh isi angket Visi Misi untuk dosen, tata usaha dan mahasiswa yang ada didalam data yang terdiri dari pilihan jawaban ya, tidak, sangat baik,baik,kurang baik dan sangat baik.

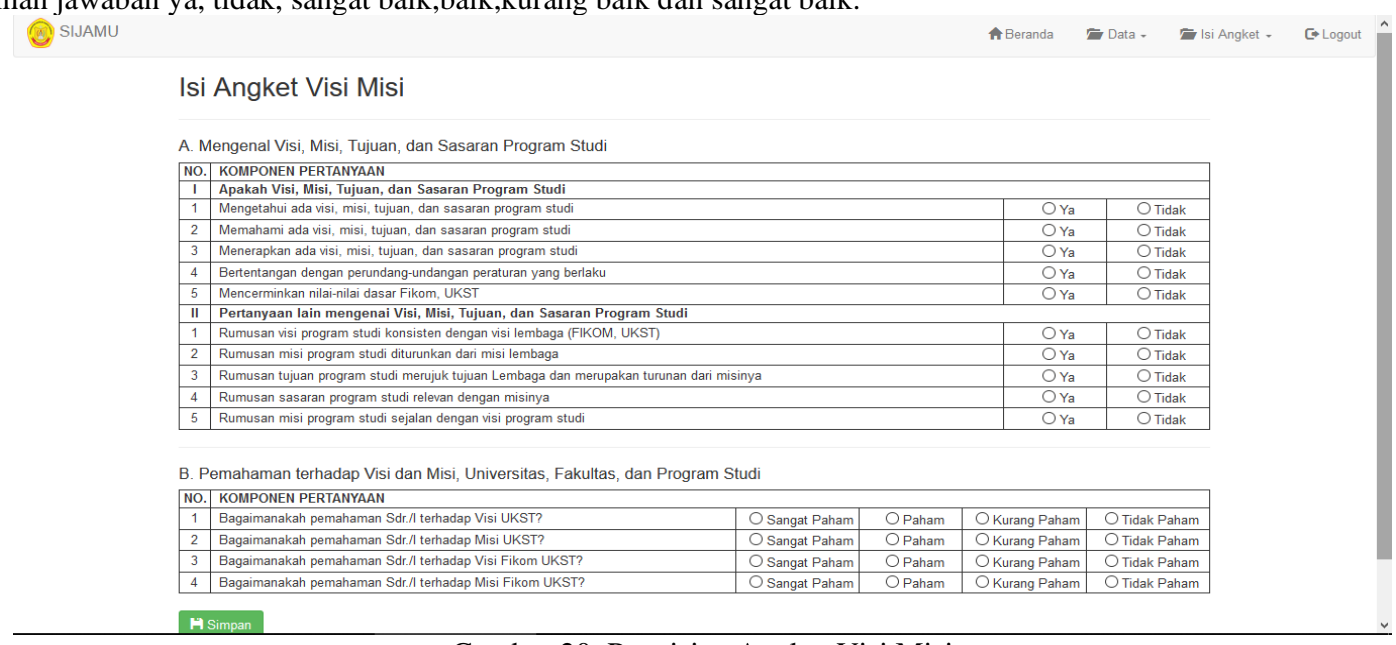

Gambar 20. Pengisian Angket Visi Misi

Gambar 21 berikut adalah contoh data jurnal, penelitian dan pengabdian dosen. Yang ada didalam data yang terdiri dari 3 tahun terakhir, berupa Menu cetak dan data 3 tahun terakhir

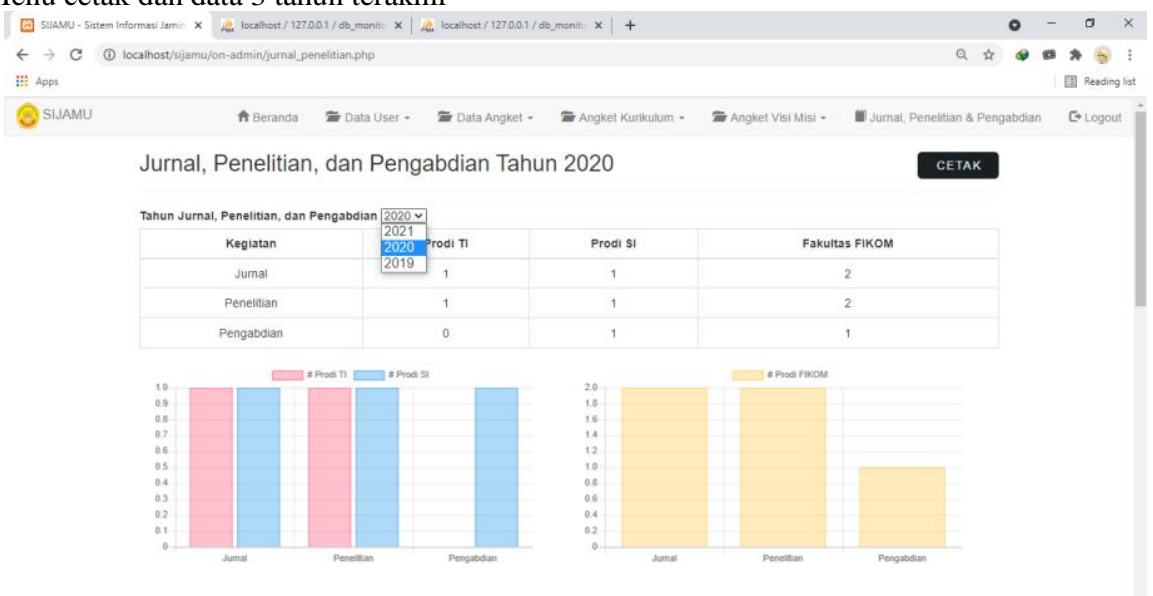

Gambar 21 Hasil Data 3 tahun terakhir

KESIMPULAN

Berdasarkan hasil pembuatan model penjaminan mutu dengan menggunakan metode Sorting metode Bubble dapat disimpulkan beberapa hal di bawah ini:

1. Dengan adanya sistem aplikasi penjaminan mutu di Fakultas Ilmu Komputer Universitas Katolik Santo Thomas dapat di buat dengan efisien. 
2. Program yang dibuat dapat diimplementasikan untuk penilaian dan disusun sedemikian rupa menjadi nilai yang berurutan yang menjadikan pedoman mutu fakultas

\section{DAFTAR PUSTAKA}

[1]. Hadis, Abdul,dkk. 2010. Manajemen Mutu Pendidikan. Jakarta: ALFABETA

[2]. Sulipan. 2009. Konsep Dasar Manajemen Mutu Terpadu.

[3]. Syafaruddin. 2002. Manajemen Mutu Terpadu dalam Pendidikan. Jakarta: PT. Grasindo

[4]. Supriyono, 2002. Akuntansi Biaya: Perencanaan dan Pengendalian Biaya, Serta Pembuatan Keputusan. Liberty Yogyakarta. Yogyakarta.

[5]. Wangsadinata, V. 2009. Sistem Pengendalian Mutu

[6]. Suendri, 2018, "Implementasi Diagram UML (Unified Modelling Language) Pada Perancangan Sistem InformasiRemunerasi DosenDengan Database Oracle”, Jurnal Ilmu Komputer dan InformatikaVolume: 03, Number: 01, November 2018 ISSN 2598-6341

[7]. Nendi Purwana, Esmeralda C. Djamal, Faiza Renaldi, 2016, “Optimalisasi Penempatan Dosen Pembimbing Dan Penjadwalan Seminar Tugas Akhir Menggunakan Algoritma Genetika”, Teknologi Informasi dan Komunikas i2016 (SENTIKA 2016) ISSN: 2089-9815

[8]. Ade Hendini, 2016, "Pemodelan Uml Sistem Informasi Monitoringpenjualan Dan Stok Barang(Studi Kasus: Distrozhezhapontianak)", Jurnal Khatulistiwa Informatika, Vol. IV, No.2 Desember 2016

[9]. Haviluddin, 2011, "Memahami Penggunaan UML (Unified Modelling Language)", Jurnal Informatika MulawarmanVol 6 No. 1 Febuari 2011

[10]. Tri A. Kurniawan, 2018, "Pemodelan Use Case (Uml): Evaluasi Terhadap Beberapa Kesalahan Dalam Praktik", Jurnal Teknologi Informasi dan Ilmu Komputer (JTIIK)DOI: 10.25126/jtiik.201851610 Vol.5, No. 1, Maret 2018, hlm.77-86p-ISSN:2355-7699 Akreditasi KEMENRISTEKDIKTI, No.51/E/KPT/2017 e-ISSN: 2528-6579

[11]. Sri Dharwiyanti, Romi Satria Wahono, 2003, "Pengantar Unified Modeling Language (UML)" IlmuKomputer.Com 